- Faktor - faktor Yang Mempengaruhi Kinerja Transaksi Berjalan Indonesia

- Indonesian Japan Economic Relations : (Investment and Trade)

- Analisis Kinerja Industri TPT Indonesia

- Kajian Atas Perlakuan Akuntansi Terhadap Skema Perdagangan Emisi (Emission Trading Scheme) Pelajaran Dari Uni Eropa dan Australia

- Kajian Kebijakan PPN Atas Bahan Bakar Minyak Untuk Kapal Tujuan Internasional (Study on Value Added Tax Policy on International Bunker Fuen

\begin{tabular}{|c|c|c|c|c|c|}
\hline Kaj. Eko. \& Keu. & Vol. 14 & No. 4 & Jakarta 2010 & $\begin{array}{c}\text { ISSN 1410- } \\
3249\end{array}$ & $\begin{array}{c}\text { Terakreditasi B } \\
\text { (No. Akreditasi : } \\
\text { 306/AU2/P2MBI/08/2010) }\end{array}$ \\
\hline
\end{tabular}




\section{K A J I A N}

EKONOMI

KEUANGAN

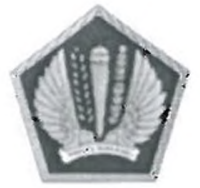

Pusat Kebijakan Ekonomi Makro

Badan Kebijakan Fiskal

Kementerian Keuangan RI

Faktor-faktor Yang Mempengaruhi Kinerja Transaksi

Berjalan Indonesia

(5)

Indonesia Japan Economic Relations: (Investment and Trade)

2

Analisis Kinerja Industri TPT Indonesia

证

Kajian Atas Perlakuan Akuntansi Terhadap Skema

Perdagangan Emisi (Emission Trading Scheme)

Pelajaran dari Uni Eropa dan Australia

Kajian Kebijakan PPN Atas Bahan Bakar Minyak. Untuk Kapal

Tujuan Internasional (Study On Value Added Tax Policy On Internasional Bunker Fuel)

\begin{tabular}{|l|l|l|l|l|}
\hline Kaj. Eko. \& Keu. & Vol. 14 & No.4 & Jakarta 2010 & ISSN 1410-3249 \\
\hline
\end{tabular} 


\section{KATA SAMBUTAN}

Kami panjatkan rasa syukur kepada Tuhan Yang Maha Esa atas terbitnya Kajian Ekonomi dan Keuangan edisi ini ke hadapan pembaca sekalian. Pada edisi ini, kami menyajikan berbagai topik yang berkaitan dengan analisis dan dampak kebijakan publik di bidang ekonomi dan keuangan negara.

Kajian pada volume kali ini diisi oleh berbagai topik tulisan yaitu FaktorFaktor yang Mempengaruhi Kinerja Transaksi Berjalan Indonesia; Indonesia Japan Economic Relations:(Investment and Trade); Analisis Kinerja Industri TPT Indonesia; Kajian Atas Perlakuan Akuntansi Terhadap Skema Perdagangan Emisi (Emission Trading Scheme) Pelajaran Dari Uni Eropa Dan Australia; dan Kajian Kebijakan PPN Atas Bahan Bakar Minyak Untuk Kapal Tujuan Internasional (Study On Value Added Tax Policy On Internasional Bunker Fuel). Adapun para penulis yang berkontribusi pada penerbitan kali ini yaitu Rudi Handoko, Suparman Zen Kemu, Ragimun, Mahpud Sujai, dan I Nyoman Widia.

Demikianlah kata pengantar yang dapat kami sampaikan. Ibarat peribahasa tiada gading yang tak retak, maka kami menyadari kajian ini tentunya masih terdapat kekurangan baik yang disengaja maupun yang tidak kami sengaja. Oleh karena itu, kami mengharapkan masukan dari para pembaca guna perbaikan di masa yang akan datang. Selanjutnya, kami berharap jurnal ini dapat memberikan manfaat kepada para pembaca sekalian. Selamat membaca!

Jakarta, 2010

Dewan Redaksi 



\section{DAFTAR ISI}

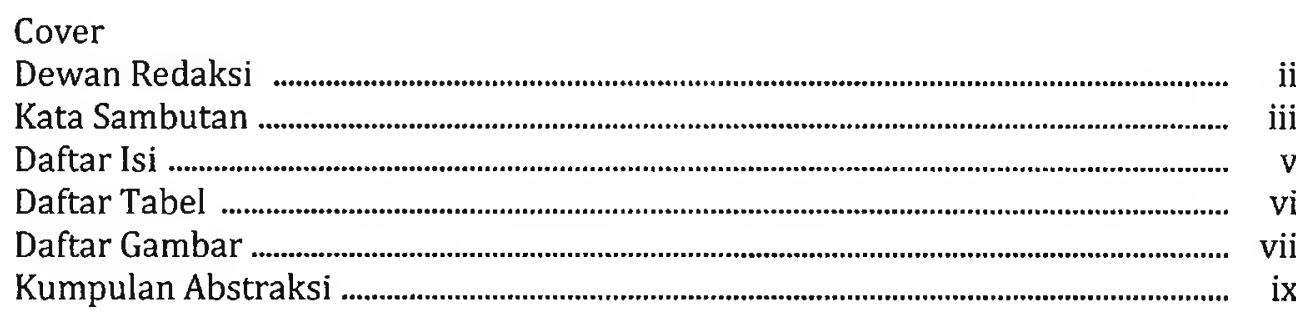

FAKTOR-FAKTOR YANG MEMPENGARUHI KINERJA TRANSAKSI

BERJALAN INDONESIA

Oleh: Rudi Handoko

INDONESIA JAPAN ECONOMIC RELATIONS:

(INVESTMENT AND TRADE)

Oleh: Suparman Zen Kemu

\section{ANALISIS KINERJA INDUSTRI TPT INDONESIA}

Oleh: Ragimun

\section{KAJIAN ATAS PERLAKUAN AKUNTANSI TERHADAP SKEMA \\ PERDAGANGAN EMISI (EMISSION TRADING SCHEME) \\ PELAJARAN DARI UNI EROPA DAN AUSTRALIA}

Oleh: Mahpud Sujai

KAJIAN KEBIJAKAN PPN ATAS BAHAN BAKAR MINYAK

UNTUK KAPAL TUJUAN INTERNASIONAL (STUDY ON VALUE ADDED

TAX POLICY ON INTERNATIONAL BUNKER FUEL)

Oleh: I Nyoman Widia 


\section{DAFTAR TABEL}

INDONESIA JAPAN ECONOMIC RELATIONS: (INVESTMENT AND TRADE)

Tabel 2.1. Japanese Foreign Investment Destination

\section{ANALISIS KINERJA INDUSTRI TPT INDONESIA}

Tabel 3.1. Profil Industri TPT Indonesia tahun 2004-2008...................................... 50

Tabel 3.2. Program Peningkatan Kinerja Industri TPT ............................................ 53

Tabel 3.3. Faktor-Faktor Yang Mempengaruhi Daya Saing Industri TPT Indonesia dengan China 57

Tabel 3.4. Struktur Biaya Tekstil dan Produk Tekstil (\%) 58

KAJIAN ATAS PERLAKUAN AKUNTANSI TERHADAP SKEMA

PERDAGANGAN EMISI (EMISSION TRADING SCHEME)

PELAJARAN DARI UNI EROPA DAN AUSTRALIA

Tabel 1.1. GHG Emissions Summary(MtCO2e)

\section{KAJIAN KEBIJAKAN PPN ATAS BAHAN BAKAR MINYAK} UNTUK KAPAL TUJUAN INTERNASIONAL (STUDY ON VALUE ADDED TAX POLICY ON INTERNASIONAL BUNKER FUEL)

Tabel 1.1. Penerimaan Perpajakan 2005 - 2010 (Triliun Rupiah) 78

Tabel 3.1. Perbandingan Penjualan BBM Indonesia dan Singapura (kilo liter) 


\section{DAFTAR GAMBAR}

\section{FAKTOR-FAKTOR YANG MEMPENGARUHI KINERJA TRANSAKSI BERJALAN INDONESIA}

Gambar 3.1. Neraca Transaksi Berjalan dan Neraca Perdagangan 1960 - 1979

(US\$ juta)

Gambar 3.2. Ekspor Minyak dan Bukan Minyak 1960 - 1979

(US\$ juta)

Gambar 3.3. Neraca Transaksi Berjalan dan Neraca Perdagangan 1980 - 1991 (US\$ juta)

Gambar 3.4. Ekspor Minyak dan Gas 1980 - 1991 (US\$ juta) 10

Gambar 3.5. Komponen Neraca Transaksi Berjalan 1992 - 2003 (US\$ juta)

Gambar 3.6. Neraca Transaksi Berjalan dan Neraca Perdagangan $1992-2003$ (US\$ juta)

Gambar 3.7. Neraca Transaksi Berjalan dan Neraca Perdagangan Q1 2004 - Q2 2010 (US\$ juta)

Gambar 3.8. Neraca Transaksi Berjalan dan Neraca Perdagangan Non Migas Q1 2004 - Q2 2010 (US\$ juta). 14

Gambar 3.9. Neraca Transaksi Berjalan dan Neraca Perdagangan Migas Q1 2004 - Q2 2010 (US\$ juta)

Gambar 3.10. Neraca Transaksi Berjalan dan Neraca Perdagangan Minyak Q1 2004 - Q2 2010 (US\$ juta)

Gambar 3.11. Neraca Transaksi Berjalan dan Neraca Perdagangan Gas Q1 $2004-$ Q2 2010 (US\$ juta)

Gambar 3.12. Neraca Transaksi Berjalan dan Jasa-jasa Q1 2004 - Q2 2010 (US\$ juta) 17

Gambar 3.13. Neraca Transaksi Berjalan dan Pendapatan Q1 2004 - Q2 2010 (US\$ juta) 18

Gambar 3.14. Neraca Transaksi Berjalan dan Transfer Q1 2004 - Q2 2010 (US\$ juta) 18

Gambar 3.15. Hubungan Transaksi Berjalan dan Pertumbuhan Ekonomi Domestik

Gambar 3.16. Hubungan Transaksi Berjalan dan Pertumbuhan Ekonomi Dunia

Gambar 3.17. Transaksi Berjalan dan Harga Komoditas. 21

Gambar 3.17. Transaksi Berjalan dan Nilai Tukar 22 
INDONESIA JAPAN ECONOMIC RELATIONS: (INVESTMENT AND TRADE)

Graph 2.1. Indonesian non-oil exports by destination country (US\$ billion)

Graph 2.2. Indonesia Japanese import and export (Billion Yen).

\section{ANALISIS KINERJA INDUSTRI TPT INDONESIA}

Grafik 3.1. Jumlah Perusahaan dan Jumlah Share Industri TPT

Tahun 2008-2009 


\begin{tabular}{|c|}
\hline $\begin{array}{l}\text { MAJALAH KAJIAN EKONOMI DAN KEUANGAN } \\
\text { ISSN 1410-3249 } \\
\text { KEK Terakreditasi B } \\
\text { (No. Akreditasi : 306/AU2/P2MBI/08/2010) } \\
\text { Volume 14 Nomor 4 Tahun } 2010\end{array}$ \\
\hline $\begin{array}{c}\text { Keywords used are free terms. Abstracts can be reproduced without } \\
\text { permission or charge. }\end{array}$ \\
\hline ABSTRAKSI \\
\hline $\begin{array}{l}\text { Handoko, Rudi, et. al. (Badan Kebijakan Fiskal, Kementerian Keuangan) } \\
\text { Faktor-Faktor Yang Mempengaruhi Kinerja Transaksi Berjalan Indonesia } \\
\text { Kajian Ekonomi dan Keuangan Volume } 14 \text { Nomor } 4 \text { Tahun 2010, halaman } \\
\text { 1-24 }\end{array}$ \\
\hline $\begin{array}{l}\text { This paper attempt to describe factors affecting the performance of current } \\
\text { account in Indonesia. Current account performance is showed by surplus or } \\
\text { deficit position. Analysis of the factors is conducted based on periodization of } \\
\text { current account performance. Other analysis was carried out by using scatter } \\
\text { graph to show the relationship between two variables in question. The results } \\
\text { show that some factors affecting current account performance are global } \\
\text { economic growth, Indonesian major trading partners growth, domestic } \\
\text { economic growth, international commodities prices, exchange rate } \\
\text { management, economic policy, and financial crisis. } \\
\text { Keyword: current account, balance of payment, externalsector, trade } \\
\text { balance }\end{array}$ \\
\hline $\begin{array}{l}\text { Zen Kemu, Suparman, et. al. (Badan Kebijakan Fiskal, Kementerian } \\
\text { Keuangan) } \\
\text { Indonesia Japan Economic Relations: (Investment and Trade) } \\
\text { Kajian Ekonomi dan Keuangan Volume } 14 \text { Nomor } 4 \text { Tahun 2010, halaman } \\
25-40\end{array}$ \\
\hline $\begin{array}{l}\text { Pra krisis ekonomi 1998, Indonesia merupakan Negara urutan ketiga dalam } \\
\text { tujuan investasi langsung Jepang (FDI), dibawah China dan Amerika Serikat. } \\
\text { Namun, paska krisis ekonomi } 1998 \text { tersebut, posisi Indonesia turun ke } \\
\text { ranking kedelapan dan telah dilewati oleh India, Thailand, Vietnam, Rusia, } \\
\text { dan Brazil. Beberapa faktor yang menyebabkan terjadinya hal ini adalah: } \\
\text { kondisi infrastruktur yang buruk di dalam negeri terutama masalah } \\
\text { perlistrikan, kurangnya kepastian hukum, adanya pajak berganda, fluktuasi }\end{array}$ \\
\hline
\end{tabular}




\begin{tabular}{|c|}
\hline $\begin{array}{c}\text { MAJALAH KAJIAN EKONOMI DAN KEUANGAN } \\
\text { ISSN 1410-3249 } \\
\text { KEK Terakreditasi B } \\
\text { (No. Akreditasi : 306/AU2/P2MBI/08/2010) } \\
\text { Volume 14 Nomor } 4 \text { Tahun } 2010\end{array}$ \\
\hline $\begin{array}{l}\text { Keywords used are free terms. Abstracts can be reproduced without } \\
\text { permission or charge. }\end{array}$ \\
\hline ABSTRAKSI \\
\hline $\begin{array}{l}\text { nilai tukar rupiah yang terlampau tajam, dan lemahnya hubungan antar } \\
\text { industrI (linkage). Dalam perdagangan luar negeri Jepang merupakan } \\
\text { partner dagang terbesar Indonesia. Pada tahun 2007, total perdagangan } \\
\text { Indonesia Jepang mencapai nilai USD 23,6, merupakan yang terbesar di } \\
\text { ASEAN dibandingkan perdagangan Negara anggota ASEAN lainnya } \\
\text { terhadap Jepang. Namun jenis ekspor Indonesia ke Jepang di dominasi oleh } \\
\text { komoditi dasar seperti minyak bumi, gas, bahan tambang, dan produk kayu. } \\
\text { Sementara ekspor Negara anggota ASEAN yang lain ke Jepang seperti } \\
\text { Singapura, Thailand dan Malaysia didominasi produk manufaktur berupa } \\
\text { komponen yang mempunyai nilai tambah lebih tinggi. Gejala lainnya adalah } \\
\text { bahwa ada tendensi peningkatan nilai perdagangan Indonesia dengan dua } \\
\text { Negara Asia Timur yaitu China dan Korea. Hal ini positif bagi Indonesia } \\
\text { namun kurang baik bagi kelanjutan hubungan ekonomi Indonesia Jepang. } \\
\text { Berbagai masalah ini perlu dibicarakan secara lebih serius oleh kedua } \\
\text { Negara agar nilai perdagangan dan investasi Indonesia Jepang dapat lebih } \\
\text { meningkat lagi. }\end{array}$ \\
\hline $\begin{array}{l}\text { Ragimun, et. al. (Badan Kebijakan Fiskal, Kementerian Keuangan) } \\
\text { Analisis Kinerja Industri TPT Indonesia } \\
\text { Kajian Ekonomi dan Keuangan Volume } 14 \text { Nomor } 4 \text { Tahun 2010, halaman } \\
\text { 41-62 }\end{array}$ \\
\hline $\begin{array}{l}\text { Textile industry can be categorized the oldest industry in Indonesia. This is a } \\
\text { significant industry, which provides not only on economic contribution but } \\
\text { also on absorbing employment for the total } 15 \% \text { of all manufacture sectors. } \\
\text { At the present, textile industry is facing some structural problems, such as the } \\
\text { high cost of energy, insufficient of infrastructure, the low technology and } \\
\text { well-worn of the machines, and also the overflowing of China's textiles into } \\
\text { Indonesia markets. Those are causing high cost of production and further } \\
\text { impeding competitiveness of domestic textile in the world market. } \\
\text { On the early stage, the textile industry development was boosted by the } \\
\text { Foreign Investment Law (1967) and the Domestic Investment Law (1968). In } \\
\text { addition, the export quota system grows up steadily during the period of } \\
1984 \text { to } 2000, \text { which reach to } 18,5 \% \text { per year. For the last } 5 \text { years, however, } \\
\text { the export shows a fluctuation. For } 2000 \text {, the number reaches US\$8.3 billion, } \\
\text { and in } 2009 \text { goes to US } \$ 9.26 \text { billion or just a tiny increase of } 3.41 \% \text { per year. }\end{array}$ \\
\hline
\end{tabular}




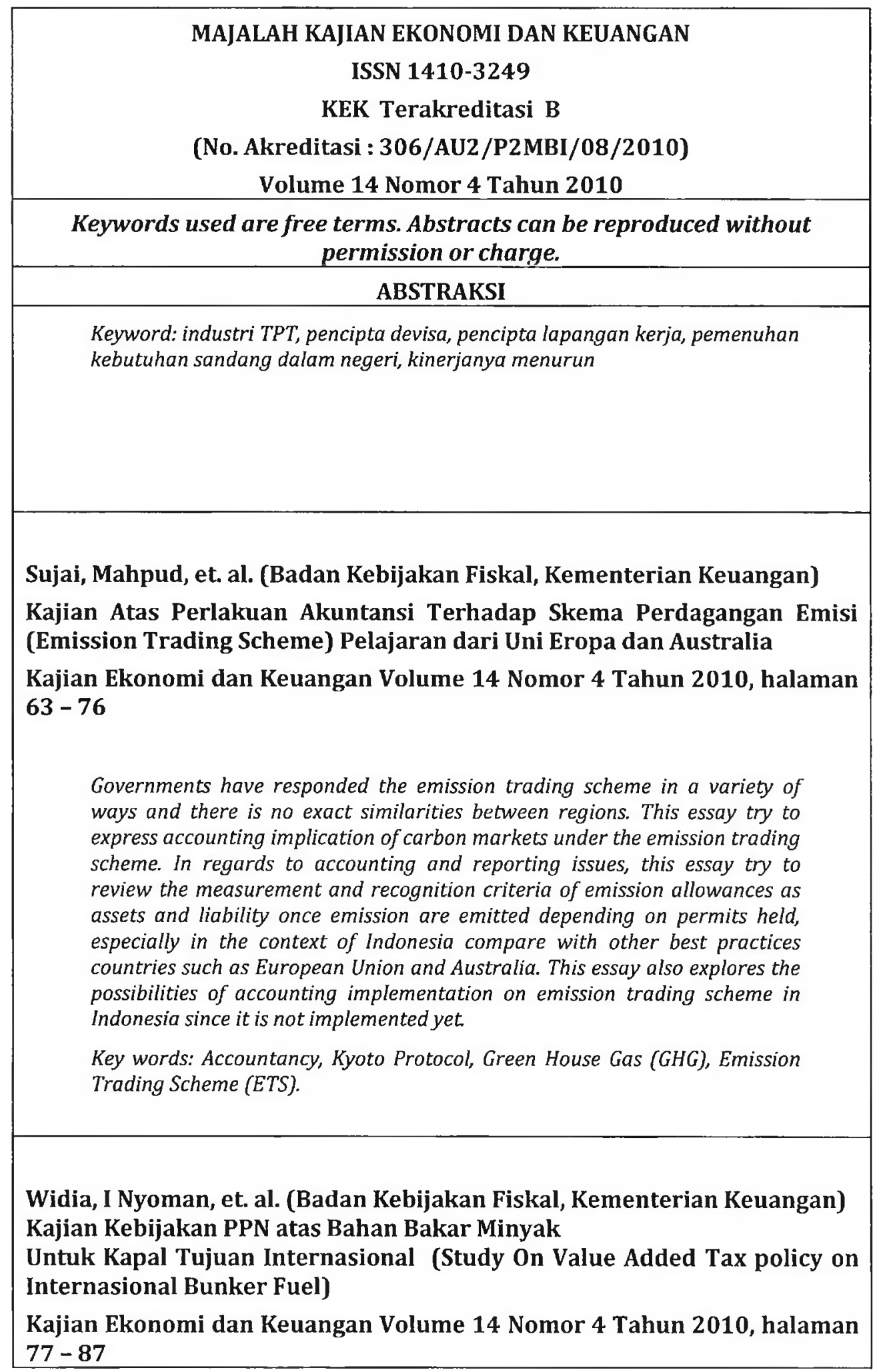


MAJALAH KAJIAN EKONOMI DAN KEUANGAN

ISSN 1410-3249

KEK Terakreditasi B

(No. Akreditasi : 306/AU2/P2MBI/08/2010)

Volume 14 Nomor 4 Tahun 2010

Keywords used are free terms. Abstracts can be reproduced without permission or charge.

ABSTRAKSI

This study focus on value added tax policy on international bunker fuel. Current regulation in Indonesia describes that government has imposed value added tax $10 \%$ on bunker fuel. Qualitative Approach was used in this study. As a result, imposing value added tax on bunker fuel against the international best practice. According to Value Added Tax Law, Government of Indonesia may give an incentive on bunker fuel.

Keywords: value added tax, international bunker fuel, incentive 


\title{
INDONESIA JAPAN ECONOMIC RELATIONS: (INVESTMENT AND TRADE)
}

By:

\author{
Suparman Zen Kemu ${ }^{1}$
}

\begin{abstract}
Pra krisis ekonomi 1998, Indonesia merupakan Negara urutan ketiga dalam tujuan investasi langsung Jepang (FDI), dibawah China dan Amerika Serikat. Namun, paska krisis ekonomi 1998 tersebut, posisi Indonesia turun ke ranking kedelapan dan telah dilewati oleh India, Thailand, Vietnam, Rusia, dan Brazil. Beberapa faktor yang menyebabkan terjadinya hal ini adalah: kondisi infrastruktur yang buruk di dalam negeri terutama masalah perlistrikan, kurangnya kepastian hukum, adanya pajak berganda, fluktuasi nilai tukar rupiah yang terlampau tajam, dan lemahnya hubungan antar industrl (linkage). Dalam perdagangan luar negeri Jepang merupakan partner dagang terbesar Indonesia. Pada tahun 2007, total perdagangan Indonesia Jepang mencapai nilai USD 23,6, merupakan yang terbesar di ASEAN dibandingkan perdagangan Negara anggota ASEAN lainnya terhadap Jepang. Namun jenis ekspor Indonesia ke Jepang di dominasi oleh komoditi dasar seperti minyak bumi, gas, bahan tambang, dan produk kayu. Sementara ekspor Negara anggota ASEAN yang lain ke Jepang seperti Singapura, Thailand dan Malaysia didominasi produk manufaktur berupa komponen yang mempunyai nilai tambah lebih tinggi. Gejala lainnya adalah bahwa ada tendensi peningkatan nilai perdagangan Indonesia dengan dua Negara Asia Timur yaitu China dan Korea. Hal ini positif bagi Indonesia namun kurang baik bagi kelanjutan hubungan ekonomi Indonesia Jepang. Berbagai masalah ini perlu dibicarakan secara lebih serius oleh kedua Negara agar nilai perdagangan dan investasi Indonesia Jepang dapat lebih meningkat lagi.
\end{abstract}

\section{INTRODUCTION}

Indonesia and Japan is a country with a big population. If Indonesia occupied the 4th place in the world with a population of around 234 million people (2008), the Japanese are on order number 10 in the world with a population of about 135 million people (2008).

Both nations have a historical relationship in particular in times of Japanese occupation in 1942 to 1945 and older periods longer at Majapait Kingdom era. ${ }^{2}$ Post-Indonesia's independence, relations between Indonesia and Japan have become very tender affection than Japanese relations with other ASEAN countries.

1 Researcher at Centre of International Cooperation Study, Fiscal Policy Office Ministry of Finance.

2 There is evidence in Trowulan Mojokerto that goods from Japan such as ceramics have been used at times Majapait 
Since the diplomatic relations established in the year 1958, Japan continued to show his attention to Indonesia. Payment of booty in Old Order era embodied in physical forms such as Hotel Indonesia, Sarinah Building, Martapura Paper Project, and Ampera Bridge in Palembang. Besides many Indonesian youths who received a scholarship to study in Japan.

By the time Suharto became president of Indonesia, and the launch of the Act no.1 of 1967 on Foreign Investment (FDI), many Japanese companies that invest in Indonesia. Call it Matshushita with electronic products, automotive companies like Toyota, Nissan, Suzuki, Honda, Masda etc.

Indonesia Japan economic relations grow stronger with the emergence of Indonesia as an exporter of energy such as oil, gas, and coal and minerals such as nickel and tin which are needed by the Japanese as an industrialized country. It is no exaggeration to say Indonesia contributed to Japan's economic progress through the supply of raw materials and energy for Japanese industry. Of course, Japan's economic progress is supported by several other factors such as the culture of hard work, human resources that have high skills, technology skills and strong capital.

Pre-1998 economic crisis, Indonesia is a Japanese investment destination number 3 in the world under China and the United States. But after the 1998 economic crisis, the situation changed drastically. Indonesia is now only occupy the country with the 8th position as an investment destination country of Japan, is shifted by Thailand, Vietnam, India, Russia, and Brazil.

It is appeared some implications of the decline in Japanese investment. First, the development of the manufacturing sector faltered and the implications for the increase in unemployment. ${ }^{3}$ Second, economic growth was not optimal because there is a potential loss of manufacturing sectors which have high value added. Third, there are de-industrialization processes in Indonesia showed by the decline of manufacturing sector contribution in Indonesia's GDP from $28 \%$ in 2007 to $27 \%$ in 2008.

In trade relations (exports and imports), Japan is Indonesia's main partner. In 2007, Indonesia Japan trade volume reached USD 30 billion, with Indonesia exported about USD 23 billion and imports from Japan amounted to USD 7 billion. Most of Indonesia's exports to Japan are oil, gas and coal (energy), and forestry products (wood), also other mining (nickel and tin). Meanwhile, many neighboring countries of ASEAN export higher value product such as components to Japan.

Some of the phenomena mentioned above tickles the author to conduct a study in order to see the latest developments and to find the cause of the condition.

3 The manufacturing sector provides many job opportunities given the high demand for labor. 


\subsection{Research Objectives}

1. To find out the obstacles encountered by Japanese investors in conducting investment (FDI) in Indonesia.

2. Seeing the development of trade relations between Indonesia and Japan.

3. Provide feedback to management about what should be done by the government, in addressing various issues related to Indonesia Japan economic cooperation.

\subsection{Research Methodology}

Methods of data collection are by gathering of secondary data from various literatures and a variety of sources including from the website. Methods of analysis done by the approach to the problems that arise both were related to FDI or foreign trade. Analytical tool is using economics, particularly international economic theory. Statistical analysis such as simple trend also used in this research.

\subsection{Scope of Study}

The aspects will be discussed in this paper are the development of foreign investment mainly from Japan, and trade (export import) of the two countries.

\subsection{Benefits of research}

The results can be used as material for making government policies; particularly the Ministry of Finance in improving the quality of relationships between two countries that has been running all the time. The results can also be used as a reference for writers who want to do further research.

\section{LITERATURE REVIEW}

Economic relations between countries are driven by two motives: (1) exchange relationships such as exchange of commodities, exchange services, exchange of capital and technology, and (2) exchange of information and communication technology (Ir. Sahibul Munir, SE, MEc). ${ }^{4}$

The relationship occurs because each country benefit from the relationship. Tell Indonesia Japan economic relations that have been underway since 1958 (51 years) and the longer the volume of these relationships is increasing. This is illustrated by the increasing of investment and trade volume of the two countries.

\footnotetext{
4 Lecturer at the University of Mercu Buana.
} 


\subsection{International Trade}

Conventional theory of international trade suggests that free world trade can improve the welfare of the countries involved in the trade. International trade theory states that each State has an absolute advantage (Adam Smith) and comparative advantage (David Ricardo) compared to other countries. ${ }^{5}$

The theory further explains that based on comparative advantage, then a country will export the commodity which has a comparative value higher, and vice versa imported commodity has a comparative advantage is lower.

Trade between countries will bring the world to use resources more efficiently, and every country can make a lucrative free trade by specializing according to their comparative advantage (Yusmichad Yusdja-2004).

\subsection{Foreign Direct Investment}

As part of the international trade activities, the company will make a direct investment in a country known as the Foreign Direct Investment (FDI). In the theory of foreign investment (FDI), there are three main things that underlie a company to invest outside the country:

1. Following the competitor.

Foreign companies follow the competitors who have done similar activities before. This paradigm was introduced by FT Knicknbocker (1973).

2. Product life cycle.

FDI done to make the efficiency of the production cycle of their products. This paradigm was introduced by Raymond (1966). ${ }^{6}$

\section{Eclectic paradigm,}

It is a combination between the two paradigms above.

\subsection{Multinational Corporation (MNC)}

Based on the argument known as "Location Specific Advantage," Company in one state not enough to just do import-export transactions with other countries, but should also make a direct investment in a State.

This argument is important to explain the basis of a company's policies in international trade activities, namely whether to export, license, or direct investment (FDI). The decision to export usually done when the lower transportation costs and trade barriers not so great. But if the cost of

5 To find out more details about the theory of Absolute Advantage and Comparative Advantage plcase read the book is international economics, especially dealing with trade issues.

6 In the early 1990s, many Korean companies that invest in the sector of footwear, because Korea had stepped on to the more advanced industries such as computers and electronics (IT). 
transportation and trade barriers is increasing, the export policy to be harmful, and the choice of strategy for the company or country is usually a license or direct investment.

According to the theory of FDI, direct investment policy is more at risk than just doing a license, though in some specific conditions the level of risk between the two in balance. Licenses would be difficult if multinational companies have several conditions as follows:

1. The company has valuable know-how and it cannot be protected in the contract.

2. The Company requires strict control of foreign production to maximize control of the market in the country concerned.

3. Expertise and capabilities cannot be included in the license

The decision to license is not the right choice for companies with the following characteristics:

1. High-tech industries, so that the protection of the company's specific expertise in licensing have high risk.

2. Global oligopoly, where a competitive interdependence, the company will likely makes strict control of foreign operations that they have the ability to implement a coordinated attack against their global competitors.

3. Industry by focusing on the suppression costs and tight control of foreign operations so that they would explore the possibility to conduct operations around the world where they found the efficiency of low-cost competitors who endanger their operations. ${ }^{7}$

Understanding the two international trade activities of export-import, and direct investment (FDI), is the key to understanding the overall matters related to international trade.

\subsection{Investment and Trade Development of Indonesia Japan}

Indonesia Japan economic relations, especially trade and investment has been running for a long time since the diplomatic relations between the two countries was established in $1958 .{ }^{8}$ Economic relations are in the form of direct investment (FDI) from Japan, and foreign trade (exports and imports) between the two countries.

7 http://eightieslovers-rockstar.blogspot.com/2009/1 l/perdagangan-internasional.html\#comment-form

8 Signed by the Minister of Foreign Affairs of Indonesia at the time Subandrio and Japanese Foreign Minister Fujiyama Aiichiro. 
investing into Indonesia. In the year 2009, (first semester), it is clearly visible decrease in Indonesian Japanese imports and export (volume of trade). Until June 2009 , Indonesian export to Japan just reached 8.8 billion yen (27.5\% of 2008). While Indonesian import from Japan just reached 366 billion yen (28.0\% of 2008), see graph-2.2.

Graph 2.2. Indonesia Japanese Import and Export

(Billion Yen)

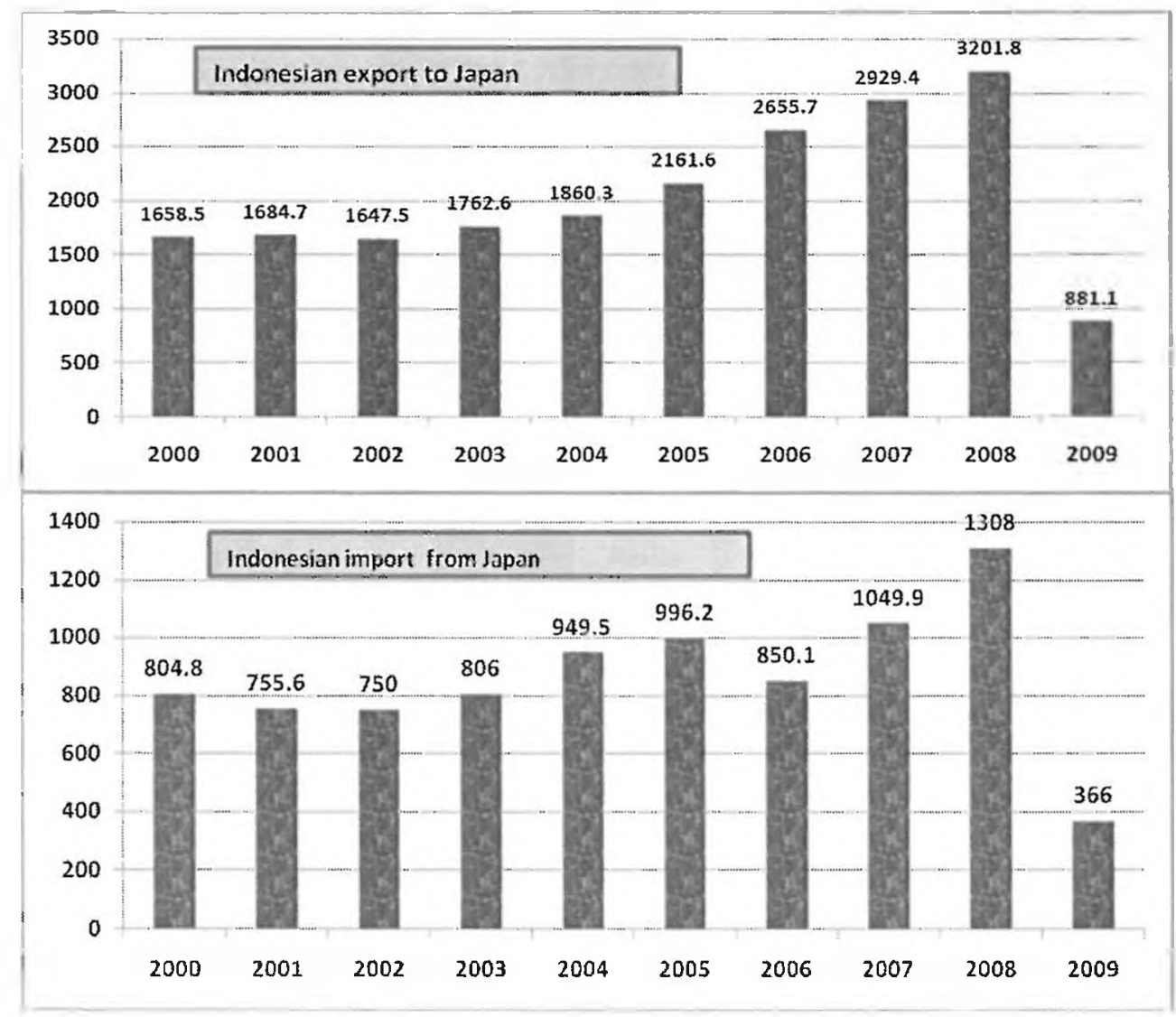

Source: Bank of Japan (BOI)

\section{ANALYSIS}

There are two aspects that concern the author would be in the analysis of the investment (FDI) and the trade (trade).

\subsection{Investment (FDI) Problems}

Japanese investment in Indonesia is a large capital base for economic growth in Indonesia. A golden period of Japanese FDI to Indonesia was since the beginning 
of the year 1970 to 1997 (the period before the crisis). At that time, Indonesia became the third state in the destination of Japanese investors after China, and the United States. Yet, the 1998 economic crisis and the shifting of political landscape in Indonesia, from the country's with authoritarian regime, to the country that very democratic, creating the interests of Japanese investors to invest in Indonesia decreased.11 This becomes even worse when the condition of several factors related to investment in Indonesia to be degraded. Take the example of poor physical condition of infrastructure, regulatory uncertainty especially tax, labor markets tend to rigid, 12 the exchange rate is very volatile, still many smuggling, licensing slow process, and something that there exists under the surface but quite disturbing is the number of red tapes (Pungli).

PT. Sony Electronics Indonesia (SEI), left Indonesia in 2003 related to issues of the labor doing mass strike in April $2000 .{ }^{13}$ In addition, the resignation of PT. SEI is related to the strategy of the parent company in Japan who tries to do the efficiency of some companies in the world, especially to be able to compete with China's electronic products. Another thing that encourages the resignation of PT. SEI was a government effort to boost tax revenue from luxury sales tax (PPn BM) for electronic products that reduce the competitiveness of PT.SEI in Indonesia market. ${ }^{14}$

\subsubsection{Infrastructure Problems}

JETRO or Japan External Trade Organization has conducted a survey of several Japanese companies that invest in Indonesia and some companies that are planning to invest in Indonesia. JETRO find several things disturbing and regarded as a risk for companies that invest in Indonesia.

The most serious problem is the problem of infrastructure with the highest score of $23.9 \%$. This means that these infrastructure problems affect the decision $23.9 \%$ Japanese investors to invest in Indonesia.

The most disturbing thing in the infrastructure is an electricity problem that is the lack of power and resulted in frequent power failure (blackouts). This is very

\footnotetext{
II The use of the word very, this is to describe the condition, according to some party called the "excessive democracy".

12 Settings too much on labor conditions such as recruitment issues, including outsourcing, layoffs issues, the provincial minimum wage issues, labor disputes. This makes the labor conditions in Indonesia to make foreign investors less comfortable, especially Japan.

${ }^{13}$ This strike was followed by 900 laborers from a total of 1500 workers PT. Sony Indonesia Electronics.

${ }^{14}$ http://masmulvo.blogspot.com/2007/11/penvebab-hengkangnya-pt-sony-electronic.html
} 
disturbing the production process and can cause financial loss and non-financial losses. 15

Recently "Kankeiren" an Economic Federation from Kansai or Osaka areas, with the mission of the delegation which numbered approximately 30 people, expressed interest in investing in Indonesia. Delegations were present among the Panasonic Corporation, Kyoei Steel Ltd, Itochu Corporation, Sumitomo Corporation, Teijin Ltd, Mitsubishi Corporation, Kansai International Airport Co.Ltd, Bando Chemical Industries Ltd, Mitsui Ltd, Rengo Co. Ltd, Mitsui Ltd, Rengo Co.Ltd, and Daikin Industries. Associated with frequent power outages has become one of the delegation concerned. For that, they asked the Indonesian government's attention to this problem.

Responding to this problem, Industry Minister MS Hidayat said that in the mid-year 2010, half of the project's first phase of 10,000 MW already in operation. Thus, the problem related to the lack of electricity supply, resulting in frequent power outages, can be overcome. At around July 2008, there were about 400 Japanese companies that threaten to leave Indonesia (resigned) to China or Vietnam due to such conditions severe electricity. Poor conditions of this electricity has also led many Japanese companies are experiencing losses. Mentioned a number of around USD 48 billion (Kompas.com July 8, 2008). 16

\subsubsection{Legal System}

According to a survey conducted by JETRO, the problem of legal system is less well ordered, and the legal implementation (the weight is $22.7 \%$ of the total problem). The most striking example is the indecisive of authority between the BKPM, BKPMD of Province and City District Government. ${ }^{17}$

There is no clear standardization between regions in determining who is responsible for capital investment problem. In one region investment areas included in the Department of Industry and Trade, other areas included in the Department of Economic Affairs, or there is also a form a separate Investment Office. Besides, there are also region that have not been able to formulate their own policies and are still very dependent on the central government. Legal uncertainty in the region may also occur due to the changes of regulations that often caused by a demonstration done by a group of people.

\footnotetext{
${ }^{15}$ Blackouts frequent problem is not only applies to Japanese investors but also distupt the entire FDI investor, and local.

${ }^{16} \mathrm{http} / / \mathrm{regional}$.kompas.com/read/xml/2008/07/08/09431178/pebisnis.lain.iuga ancam.hengkang

${ }^{17} \mathrm{BKPM}$ is Investment Coordinating Board (central government), and BKPMD is Regional Investment Coordinating Board (province and municipality).
} 


\subsubsection{Exchange Rate Risk}

The investors, especially foreign investors are concerned with the problem of exchange rate stability. Because the implications of large exchange rate fluctuations will impact to a broad aspect of the business. In terms of raw materials, intermediate materials, and capital, exchange rate fluctuations will affect the import price. Moreover, the nature of the investments made in Indonesia is still very dependent on imported goods and materials. In terms of tax payments, exchange rate fluctuations will also affect the amount of import taxes to be paid either import duties (BM), or import VAT and Import Income Tax.

According to some sources, these investors are not so questioning throughout the fluctuations if it is in the range of $5 \%$. More than $5 \%$ will have an impact on the company through various aspects as mentioned above. High exchange rate fluctuations did not benefit the company except for currency speculators. The high fluctuations of exchange rates in Indonesia become a Japanese investor concern of $15 \%$. Bank Indonesia is the party most responsible for these foreign currency fluctuations. Hence, BI was asked to optimize the monetary instrument, either through determination of the BI rate, and market operations.

\subsubsection{The Development of Related Industries}

In industry, there is the technical term named industrial linkages that can be divided into two, namely backward linkages and forward linkages. An industry greatly depends on their backward industry and forward industry. As an illustrative example the textile industry has spinning industry as backward industry, while garment industry is the forward industry. Another example is the automotive industry, where components industry in the backward and transportation industry in the forward.

A company intends to invest in one type of industry in a country, usually to see the condition of backward and forward linkage of an industry. This is important because an industry is very interested in the input from backward industries, and marketing of products in forward industries. Currently the development of this backward and forward industry will greatly affect an investment decision.

In Indonesia, the local industry linkage can be said as still very weak, it is seen from the still high import component that describes the inability of the domestic components industry to meet the needs of downstream industries. This is especially seen in the automotive industry and electronics industry that is still highly dependent on imported components. Currently stage of related industries in 
Indonesia is receiving a share of $13.3 \%$ in the Japanese investor's decision to invest in Indonesia.

\subsubsection{Employment}

There are some Japanese investors complaints relating to this employment issue. First is the problem related to recruitment of employees that are given limitations on use of foreign workers. The company also charged $\$ 100$ per foreign worker per month. This is a heavy burden for the company. If a company employs 100 people of foreign workers, then every month the company must pay of USD 10,000 or approximately $\mathrm{Rp} 94,000,000,-$ (Ninety-four million rupiah).

Second, is the minimum wage provision. This also disrupts the Japanese investors because the minimum wage set by the local government is often based on the number of demonstrations demanding a wage increase. While on the other hand, wage increases are not matched with the increased of productivity. This means that companies must pay more to workers to produce a unit of the same item.

Third, the rule providing a severance for employee that experienced termination (PHK). The provisions of this severance into a separate complaint from Japanese companies. For many cases, where employees are dismissed because the performance is not good, but when the company lay off the employer still have to pay severance to these workers. These labor problems are receiving a share of $9.1 \%$ as a barrier to the entry of investors into Indonesia.

\subsubsection{Tax Problems}

Tax problem is often complained by Japanese investors due to tax levies by the government have an impact on the price of their products. Call it luxury sales tax (PPn BM) is imposed on the pricing of electronic products that is high enough. This resulted in higher selling prices in the market and affects the declining competitiveness.

With the implementation of regional autonomy, since 2001, regional governments publishing so many taxes and levies regulation cause problems for investors. Many of the tax laws and publishes regional Levies burden investors. According to Chamber of Commerce data (KADIN), 14.7\% of the regional tax, and $72.2 \%$ levy on related to areas of business.

Still related to taxation, investors complain the high tax rate, taxes too much, and double taxation. This caused the tax and law enforcement looking for opportunities to trap and extract Investors and relevant agencies. If it's this way, the investor must spend more to bribe the law enforcement elements to the business can run smoothly. 
Based on a survey conducted by the World Bank, the company must pay a tax of $38 \%$ of gross profits. In addition, the employer must set aside 560 hours per year or 2 months 10 days in a year to take care of tax payments. (Wawan Fahrudin). According to JETRO, tax issues related risk is $8 \%$ of the overall risk of investing in Indonesia.

\subsubsection{Problems of Intellectual Property Rights (Property Rights)}

Internationally, the issue of Intellectual Property Rights (IPR) is set in the Agreement on Trade Related Aspects of Intellectual Property Rights (TRIPS Agreement). Currently, Indonesia already has a device legislation in the field of intellectual property rights are adequate and not contrary to the provisions as required in the TRIPS Agreement. Regulation of legislation referred to include:

1. Act. No.12 Year 1997 on Amendment of Act No. 6/1982 on Copyright as amended by Law No. 7 in 1987 (Copyright Act); in the near future, this law will be revised to accommodate recent developments in the field of copyright;

2. Act. No. 29 of $\mathbf{2 0 0 0}$ on Plant Variety Protection;

3. Act No. 30 of 2000 on Trade Secret;

4. Act No. 31 Year 2000 on Industrial Design;

5. Act No. 32 of 2000 on Layout Designs of Integrated Circuits;

6. Act No. 14 of 2001 on Patents (Patent Law); and

7. Act No. 15 in 2001 about brands.

Indonesia has also ratified the international convention on 5 areas of intellectual property rights, is as follows:

1. Paris Convention for the Protection of Industrial Property and the Convention Establishing the World Intellectual Property Organization (Presidential Decree No. 15 year 1997 concerning Amendment to Presidential Decree No. 24 of 1979);

2. Patent Cooperation Treaty (PCT) and Regulations under the PCT (Presidential Decree No. 16 of 1997);

3. Trademark Law Treaty (Presidential Decree No. 17 of 1997);

4. Berne Convention for the Protection of Literary and Artistic Works (Presidential Decree No. 18 of 1997);

5. WIPO Copyright Treaty (Presidential Decree No. 19 of 1997).

If look at the number of IPR rules that have been made in Indonesia, is also quite surprising that the results of research conducted by JETRO, where IPR issues are receiving a share of $8 \%$ as a factor inhibiting the entry of Japanese investors to Indonesia. As a member of the World Trade Organization (WTO), the Indonesia response is quite high in IPR issues. It is seen from the number of IPR rules are 
published. But if the IPR issue is still a problem for Japanese investors, perhaps that the rules are not applied correctly. For that, the government needs to supervise the implementation of IPR rules which have made it.

\subsection{Trade Problems}

After conducting an analysis of investment issues, especially the problems faced by Japanese investors in investing in Indonesia, following the author tries to analyze issues related to trade (exports-imports). For Indonesia, Japan is the country's largest trading partner. In 2007, Indonesian exports to Japan worth USD 23.6 billion (Gol statistics), while Japanese imports from Indonesia was USD 6.5 billion. This means that Indonesia had a trade surplus of USD 17.1 billion.

Important commodities imported by Japan from Indonesia such as petroleum, liquefied natural gas, coal, mining, shrimp, pulp, textiles and textile products, and electrical equipment. On the other hand, the goods Japan exports to Indonesia include vehicle, machinery and parts, plastics and chemical products, steel, electrical equipment, electronic parts, machinery and transportation equipment parts.

Trades between the two countries actually benefit Indonesia. It is seen from the large value of Indonesia's trade surplus with Japan. But there are some weaknesses that deserve presented in this paper.

Indonesia's exports are dominated by energy products (oil and coal) and other primary commodities such as timber and minerals like nickel, tin, aluminum and others. While for the portion of manufactured goods is still very low (range $20 \%$ of total). Some neighboring countries such as Thailand, Malaysia, and Singapore to export more manufactured goods, a component that will be used by industry in Japan (finished goods). Indeed this does not depart from the strategy that Japan distinguishes Indonesia from the neighbors.

Indonesian larger market causing Japanese component companies operating in Indonesia more major products for domestic needs (Indonesia). Whereas in the case of Malaysia, or Singapore the situation is different, where both countries it was used as the base for Japanese companies for export purposes, including for export to Japan. So it is natural that the two components of the role of state exports are higher than Indonesia.

Learning from this situation, Indonesia should begin to prepare them to be the goal of Japanese investors with a target of producing components for export. Indeed it is not easy but it can be done if Indonesia prepares several things such as: improving the conditions of the relevant investment as has been discussed in advance, and prepares more qualified human resources. From the fiscal side, government can provide incentives such as tax cuts and if necessary tax holiday for Japanese companies interested to invest in the components industry. 
Indonesia also had to anticipate that once the Japanese energy imports could be reduced for finding green energy technologies. If Indonesia still relies on exports in the energy sector alone, and the less developed non-oil exports. So not an impossible thing if one day Indonesia's exports to Japan bypassed by neighboring countries.

Another interesting phenomena in the Indonesia Japan trade is the tendency that Indonesia to start a new trade partners from two countries that are emerging markets in Asia, namely China and Korea. In the last three years, an increase in Indonesian exports to these two countries respectively $96 \%$ of China and $81 \%$ of Korea. This is positive for Indonesia, but negative for Indonesia Japan economic relations. Therefore, Japanese and Indonesian parties need to sit together to discuss the issue of trade relations for the benefit of both parties.

\section{CONCLUSIONS}

From the analysis has been done, some interesting things to get attention, namely: On the investment side there are some disturbing factors perceived Japanese investors in conducting its investment in Indonesia, (i) The problem of infrastructure particularly shortages of electricity (ii) The problem of legal uncertainty ( iii) Exchange rate fluctuations problem (iv) Issues related to the development of linkage industry ( $v$ ) The problem of employment regulations (vi) The problem of overlapping tax, and (vii) The problem of intellectual property rights.

Indonesian exports to Japan has been dominated by energy products such as oil, natural gas, and coal as well as primary goods such as wood and wood products, minerals such as nickel. In the future, efforts should be made to the contribution of manufactured products; especially components can be larger role in Indonesian exports to Japan. Therefore, Indonesia must strengthen the factors for increased domestic production of components, such as human resource capacity (technology). Tax incentives (if needed tax holiday), improve the infrastructure especially the electricity, and other factors which support the FDI from Japan for the purpose of export oriented, especially export to Japan.

There are the tendencies of decline of trade relations with Japan as a result of the global crisis. Besides, there is a trend increase in trade relations of Indonesia with the two countries are emerging markets of China and Korea. This can interfere Indonesia trade relations with Japan in the future. For that, it is necessary the existence of a more serious discussion on both sides of both government and private sector to improve trade relations between the two countries particularly exports and imports. 


\section{References}

Fahrudin, Wawan: "Mengkaji Iklim Investasi dan Kepastian Hukum di Daerah - 13 Februari 2009". Pathways Institute.

Knickerbocker, F. (1973): Oligopolistic reaction and multinational enterprise, Boston, Harvard School of Business Administration.

Munir, Sahibul, Ir. SE, MEc: "Pengantar Ekonomi Internasional" (Modul 11) $2007-$ 2008.

Prakosa, Kesit Bambang: "Analisis Pengaruh Kebijakan Tax Holiday terhadap Perkembangan Penanaman Modal Asing di Indonesia (Tahun 1970-1999)". Jurnal Ekonomi Pembangunan. Kajian Ekonomi Negara Berkembang. Hal: 1937

Sanusi, Anwar: "Analysis the influence of Economic Factors on Fluctuation of Rupiah Exchange 2000-2002". Program Pascasarjana Universitas Sumatera Utara Medan 2004.

Suwismo, Andryanto:"Outlook Industri Manufaktur 2008, Mengikis Bayang-bayang Deindustrialisasi." Investor Daily (ex Investor Indonesia). Oktober 7, 2008. http://suraniningsih.wordpress.com/2008/10/07/outlook-industrimanufaktur-2008-mengikis-bayang-bayang-deindustrialisasi/

Vernon, Raymond, "International Investment and International Trade in the Product Life Cycle," Quarterly Journal of Economics, 80 (1966):190-207.

Yusdja, Yusmichad: "Tinjauan Teori Perdagangan Internasional dan Keunggulan Komparatif". Puslitbang Sosial Ekonomi Pertanian IPB Bogor-2004. 